Check for updates

Cite this: RSC Adv., 2018, 8, 35897

\title{
Stereoselective degradation behaviour of carfentrazone-ethyl and its metabolite carfentrazone in soils
}

\author{
Jinsheng Duan, ${ }^{\mathrm{ab}}$ Beibei Gao, ${ }^{\mathrm{a}}$ Xu Dong, ${ }^{\mathrm{b}}$ Mingna Sun, ${ }^{\mathrm{b}}$ Yang Shen, ${ }^{\mathrm{b}}$ Zhaoxian Zhang, ${ }^{\mathrm{a}}$ \\ Tongchun Gao ${ }^{\mathrm{b}}$ and Minghua Wang (D) *a
}

\begin{abstract}
The stereoselective environmental behaviour of carfentrazone-ethyl and its metabolite carfentrazone enantiomer in three types of soil were studied under aerobic conditions. Under aerobic conditions, significant stereoselective difference in the degradation behaviour of carfentrazone-ethyl and its metabolite carfentrazone enantiomer was observed in Jiangxi red soil, Jilin black soil and Anhui paddy soil. The EF values of the carfentrazone-ethyl enantiomers in Anhui paddy soil, Jilin black soil, and Jiangxi red soil were $0.67,0.65$ and 0.57 , respectively. The EF values of the carfentrazone enantiomer in the three types of soil were $0.75,0.80$ and 0.76 . No bidirectional chiral inversion of enantiopure carfentrazone-ethyl and carfentrazone enantiomers was observed in Jilin soil. As a result, $R$ $(+)$-carfentrazone-ethyl and $S$-(+)-carfentrazone in soil would be preferentially degraded, while $S$ $(-)$-carfentrazone-ethyl and $R-(-)$-carfentrazone were enriched. The results found in this paper could provide more scientific guidance for the risk assessments of carfentrazone-ethyl from a chiral perspective.
\end{abstract}

Received 7th June 2018

Accepted 15th October 2018

DOI: $10.1039 / \mathrm{c} 8 \mathrm{ra04873h}$

rsc.li/rsc-advances of metalaxyl in soil is closely related with the soil $\mathrm{pH} .{ }^{16}$ When the soil $\mathrm{pH}>5$, the $R$-enantiomer of metalaxyl showed a higher degradation rate. When $4<\mathrm{pH}<5$, the degradation rates of the two enantiomers were roughly equal, and the S-enantiomer was preferentially degraded when $\mathrm{pH}<4$. Romero et al. discovered that the $S$-enantiomers of 2-methyl-chlorophenoxypropionic acid and 2,4-D-propionic acid in the sludge and the sandy soil remained for a longer period than the $R$-enantiomers, but the opposite phenomenon was observed in clay. ${ }^{17}$ In the three types of soil, the $R$-enantiomers of the two herbicides could be transformed into the $S$-enantiomers. Poiger et al. studied the stereoselective degradation of haloxyfop-2-ethoxyethyl in soils and found that haloxyfop-2-ethoxyethyl could transfer to piperoxolinic acid in fresh soils with the passage of time, and the $S$-enantiomer could transform to the $R$-enantiomer quickly. ${ }^{18}$ Sun et al. studied the degradation behaviors of the indoxacarb enantiomers in different types of agricultural field soil and found that the indoxacarb enantiomers degraded quickly in alkali soil while degraded not so quickly as that in acid soils. ${ }^{19}$ Moreover, they discussed the effects of the soil organic matter content on the degradation of the indoxacarb enantiomers and concluded that the higher organic matter content could result in a stronger selective degradation behaviour.

Carfentrazone-ethyl is a broad-spectrum, systemic, selective post-emergence triazolone herbicide. Carfentrazone-ethyl inhibit the activity of the protoporphyrin oxidase(PPO) and interfere the chlorophyll biosynthetic pathway of plants. It has been widely used to control broadleaf grasses in crop fields, 
such as rice, wheat, soybean and corn. To date, the existing studies on the degradation behaviours of carfentrazone-ethyl residues mainly focused on racemes. ${ }^{20,21}$ As for the studies on the stereoselective degradation behaviours of carfentrazoneethyl and its metabolite carfentrazone still without report.

In this study, a chiral multiresidues analysis method of the chiral carfentrazone-ethyl and its chiral metabolites carfentrazone enantiomers in soils were established on the basis of the optimization of the QuEchERS method and LC MS/MS. The stereoselective degradation behaviors of carfentrazone-ethyl and carfentrazone enantiomers in different soils were studied for the first time through an indoor incubation test. The degradation of enantiopure carfentrazone-ethyl and carfentrazone isomers in Jilin soil was used to study the chiral stability. This paper could provide scientific and theoretical references for the environmental risks evaluation of carfentrazone-ethyl.

\section{Materials and methods}

\subsection{Reagents and materials}

The carfentrazone-ethyl raceme (95\% purity) was provided by Institute for the Control of Agrochemicals, Ministry of Agriculture (Beijing, China). $R$-(+)-Carfentrazone-ethyl, $S$-(-)-carfentrazone-ethyl, $S$-(+)-carfentrazone and $R$-(-)-carfentrazone $(>95 \%$ purity and $>98 \%$ optical purity) were prepared by Shanghai Qinlu Biotech Co., Ltd. (Shanghai, China). Chromatography grade methanol and acetonitrile were obtained from TEDIA (Fairfield, Connecticut, USA). Chromatographically pure ammonium acetate and formic acid were obtained from Aladdin Biotech Co., Ltd. (Shanghai, China). The ultra-pure water was Watsons purified water.

The dispersing agents primary secondary amine (PSA) was provided by Bonar Agela Technology Company (Tianjin, China). Analytical grade acetonitrile, anhydrous magnesium sulphate and sodium chloride were obtained from the National Pharmaceutical Chemical Reagent Company (Shanghai, China). Enantioseparation and analyses were performed using an LCMS-8030 ultra-high-performance liquid chromatography tandem mass spectrometry (Shimadzu, Japan) equipped with Super-chiral S-AD-RH $(150 \mathrm{~mm} \times 4.6 \mathrm{~mm}, 5 \mu \mathrm{m})$ (Shanghai Qinlu Biotech Co., Ltd, Shanghai, China); CHIRALCEL AD-3R $(150 \mathrm{~mm} \times 2.1 \mathrm{~mm}, 3 \mu \mathrm{m})$ (Daicel, Tokyo, Japan) and CHIRALCEL OD-3R(150 mm $\times 2.1 \mathrm{~mm}, 3 \mu \mathrm{m})$ (Daicel, Tokyo, Japan). The HC-3018 high-speed centrifuge (Anhui Zhongke Zhongjia Scientific Instrument Co., Ltd. Hefei, China), M3 vortex oscillator (IKA company, Germany), and a nylon filter membrane (0.22 $\mu \mathrm{m}$, ANPEL Company, USA) were used.

\subsection{Soil sample preparation}

Three kinds of soils (Jilin black soil, Jiangxi red soil and Anhui paddy soil) representing different physicochemical properties and climatic environments were collected from the $0-10 \mathrm{~cm}$ agricultural field and mixed thoroughly. The soil samples were air-dried and sifted by a $2 \mathrm{~mm}$ sieve, and then stored in the dark at $4{ }^{\circ} \mathrm{C}$. The physicochemical parameters of the three kinds of soils were listed in Table 1.

\subsection{Soil pre-culture}

Approximately $2 \mathrm{~kg}$ of each types of soil samples were precultured at $25{ }^{\circ} \mathrm{C}$, respectively. Meanwhile, water was sprayed on the soils to keep the water content at $60 \%$ of saturation moisture capacity of the soils. The soils were incubated for 2 weeks at $25{ }^{\circ} \mathrm{C}$. During the culture, the water contents of the soils were adjusted timely to maintain the original state. The saturation moisture capacities of the paddy soil in Anhui, red soil in Jiangxi and black soil in Jilin were $23 \%, 21 \%$ and $30 \%$, respectively.

\subsection{Soil degradation test}

Pre-cultured soils were air-dried, smashed and passed through the $2 \mathrm{~mm}$ sieve. Then $20 \mathrm{~g}$ soil samples were weighed into $250 \mathrm{~mL}$ brown conical flasks, and $200 \mu \mathrm{g}$ of racemic carfentrazone-ethyl was added and mixed in Anhui, Jiangxi and Jilin soils. Enantiopure carfentrazone-ethyl and carfentrazone isomers $(200 \mu \mathrm{g})$ were added into Jilin soil to investigate the chiral stability. After then, water was added to adjust the soil water content to $60 \%$ of the saturation moisture capacity. The flask was plugged with a ventilation silica gel and then cultured in the dark at $25^{\circ} \mathrm{C}$. Triplicate samples were collected at 2, 4, 6, $8 \mathrm{~h}, 1,2,3,5,7,14,21$ and $30 \mathrm{~d}$ during the culture. And in the process of the culture, the water content was adjusted timely to maintain the original state. Meanwhile, the blank control group was set.

\subsection{Samples extract and clean-up}

The carfentrazone-ethyl and carfentrazone enantiomers in soil were determined according to methods described by Duan et $a .^{22}$ In short, $10 \mathrm{~g}$ soil samples were weighted into a $50 \mathrm{~mL}$ Teflon centrifuge tubes with plugs. Next, $10 \mathrm{~mL}$ of water and $20 \mathrm{~mL}$ of acetonitrile were added and the tubes were shaken vigorously for $30 \mathrm{~min}$. Subsequently, $3 \mathrm{~g}$ anhydrous magnesium sulphate and $1 \mathrm{~g}$ sodium chloride were added and the tubes were oscillated violently for $2 \mathrm{~min}$. The centrifuge tubes were centrifuged for $5 \mathrm{~min}$ at $3000 \mathrm{rpm}$. Then, $1.5 \mathrm{~mL}$ upper organic

Table 1 Physicochemical parameters of the three kinds of soil samples

\begin{tabular}{lllll}
\hline Soil type & pH & $\begin{array}{l}\text { Organic } \\
\text { content }(\%)\end{array}$ & Mechanical composition \% & $\begin{array}{c}\text { Cation exchange } \\
\text { capacity }\left(\mathrm{cmol} \mathrm{kg}^{-1} \text { ) }\right.\end{array}$ \\
\hline Jilin black soil & 6.75 & 3.39 & Clay: $26.8 \%$; powder (sand): $14.6 \%$; fine sand: $53.4 \%$; coarse sand: $5.17 \%$ & 28.1 \\
Jiangxi red soil & 5.21 & 0.91 & Clay: $3.0 \%$; powder (sand): $14.9 \%$; fine sand: $36.1 \%$; coarse sand: $46.0 \%$ & 6.56 \\
Anhui paddy soil & 7.06 & 1.73 & Clay: $3.0 \%$; powder (sand): $15.4 \%$; fine sand: $78.0 \%$; coarse sand: $3.62 \%$ & 16.4
\end{tabular}


phase was transferred into a $10 \mathrm{~mL}$ centrifugal tube containing $50 \mathrm{mg}$ of PSA and $100 \mathrm{mg}$ of anhydrous magnesium sulphate and vortexed for $1 \mathrm{~min}$. The tube was centrifugated at $5000 \mathrm{rpm}$ for $3 \mathrm{~min}$, the supernatant was filtered by a $0.22 \mu \mathrm{m}$ nylon syringe filter and for UPLC-MS/MS analysis.

\subsection{Chiral separation and detection}

The separation potency of three columns (CHIRALPAK AD-3R, CHIRALCEL OD-3R and Super-chiral S-AD-RH) have been investigated in this study. Among those columns only Superchiral S-AD-RH can achieve the simultaneously separation of carfentrazone-ethyl and carfentrazone enantiomers. So, Superchiral S-AD-RH was chosen for the further degradation experiment. The separation and detection of the carfentrazone-ethyl and carfentrazone enantiomers were performed by the UPLCMS/MS with a super chiral S-AD column $(150 \mathrm{~mm} \times 4.6 \mathrm{~mm})$. The mixture of a $10 \mathrm{mmol} \mathrm{L}{ }^{-1}$ ammonium acetate aqueous solution and methanol (containing $0.1 \%$ formic acid) was used as the mobile phase at the flow rate of $0.4 \mathrm{~mL} \mathrm{~min}^{-1}$. The injection volume and column temperature were $5 \mu \mathrm{L}$ and $35^{\circ} \mathrm{C}$, respectively. Gradient elution was adopted and the elution order of four compounds was $S$-(+)-carfentrazone, $R$-(-)-carfentrazone, $S$-(-)-carfentrazone-ethyl and $R$-(+)-carfentrazoneethyl, respectively ${ }^{22}$

An electronic spray ion source with positive ion (ESI+) ionization in the MRM mode. The capillary voltage was $4.5 \mathrm{kV}$. The desolvation tube temperature and the heating module temperature were $250{ }^{\circ} \mathrm{C}$ and $450{ }^{\circ} \mathrm{C}$, respectively. High-purity nitrogen was used as both the atomization gas and the drying gas with the gas flow of $3.0 \mathrm{~L} \mathrm{~h}^{-1}$ and $20 \mathrm{~L} \mathrm{~h}^{-1}$, respectively. The highpurity argon was used as collision gas. The quantitative ion pair of carfentrazone-ethyl was $\mathrm{m} / \mathrm{z} 429.05>412.00$, and the qualitative ion pair was $\mathrm{m} / \mathrm{z} 429.05>346.00$ and $\mathrm{m} / \mathrm{z} 429.05>$ 366.00. Correspondingly, the quantitative ion pair of carfentrazone was $m / z 401.00>383.90$, while the qualitative ion pair was $m / z 401.00>365.90$ and $m / z 401.00>345.85 .^{22}$

\subsection{Method validation}

2.7.1 Standard curves. Individual standard solutions (1000 $\mathrm{mg} \mathrm{L}^{-1}$ ) in methanol of carfentrazone-ethyl and carfentrazone enantiomer were diluted to serial concentrations $(5,10$, $50,100,500$ and $1000 \mu \mathrm{g} \mathrm{L}^{-1}$ ) of mixed standard solutions with methanol. Correspondingly, the matrix-matched standard solutions were obtained at same concentration by adding appropriate amounts of standards to blank sample extract. The linearity of the calibration curves was evaluated based on the peak areas and concentrations of standard solutions and matrix-matched standard solutions using Microsoft Excel.

\subsection{Data processing}

The degradation rate constant $(k)$ of the carfentrazone-ethyl enantiomer in the soils was calculated using the first-order kinetic equation. The variation with time of the residual concentration was listed as follows: ${ }^{23}$

$$
\begin{gathered}
C=C_{0} \mathrm{e}^{-k t} \\
T_{1 / 2}=\ln 2 / k=0.693 / k
\end{gathered}
$$

where $C_{0}$ is the initial concentration of the carfentrazone-ethyl enantiomer in the samples $\left(\mathrm{mg} \mathrm{kg}^{-1}\right), C$ is the concentration of the carfentrazone-ethyl enantiomer at $t$ time $\left(\mathrm{mg} \mathrm{kg}^{-1}\right), k$ is the degradation rate constant and $t$ is time after the application of the pesticides. $T_{1 / 2}$ is the degradation half-life of the enantiomers.

The enantioselective degradation of carfentrazone-ethyl or the carfentrazone enantiomer was evaluated using the enantiomeric fraction $(\mathrm{EF})$ :

$$
\mathrm{EF}=(-) \text {-enantiomer } /[(-) \text {-enantiomer }+(+) \text {-enantiomer }]
$$

The EF value was between 0 and 1 . When $\mathrm{EF}=0.5$, the degradation rates of the two enantiomers were same and no enantiomer selectivity. When EF $>0.5,(+)$-enantiomer degraded preferentially. When $\mathrm{EF}<0.5,(-)$-enantiomer degraded faster. The more the EF value deviated from 0.5, the stronger the stereoselectivity behaviour of the carfentrazone-ethyl and carfentrazone enantiomers in the samples.

\section{Results and analysis}

\subsection{Standard curve and linearity}

As shown in Table 2, excellent linearity in the range of 5 to $1000 \mu \mathrm{g}$ $\mathrm{L}^{-1}$ for carfentrazone-ethyl and the carfentrazone enantiomers were obtained with correlation coefficients $\left(R^{2}\right) \geq 0.9986$. The slope ratio of the solvent calibration curves via matrix-matched

\begin{tabular}{|c|c|c|c|c|c|c|}
\hline Compounds & Matrix & Linear equation & $R^{2}$ & Matrix slope/solvent slope & $\operatorname{LOD}\left(\mu \mathrm{g} \mathrm{kg}^{-1}\right)$ & $\operatorname{LOQ}\left(\mu \mathrm{g} \mathrm{kg}{ }^{-1}\right)$ \\
\hline \multirow[t]{2}{*}{$R-(+)$-Carfentrazone-ethyl } & Solvent & $y=16397 x+75981$ & 0.9986 & - & 0.5 & 1.7 \\
\hline & Soil & $y=17704 x+63619$ & 1.0 & 1.08 & 3.0 & 10 \\
\hline \multirow[t]{2}{*}{$S$-(-)-Carfentrazone-ethyl } & Solvent & $y=14378 x+58805$ & 0.9996 & - & 0.5 & 1.7 \\
\hline & Soil & $y=17253 x-21556$ & 0.9994 & 1.20 & 3.0 & 10 \\
\hline \multirow[t]{2}{*}{$S$-(+)-Carfentrazone } & Solvent & $y=4679.1 x+14866$ & 0.9997 & - & 1.0 & 3.5 \\
\hline & Soil & $y=5058.8 x+15214$ & 1.0 & 1.08 & 3.0 & 10 \\
\hline \multirow[t]{2}{*}{$R$-(-)-Carfentrazone } & Solvent & $y=3023.7 x+10696$ & 0.9994 & - & 2.0 & 7.0 \\
\hline & Soil & $y=3063.6 x+16313$ & 1.0 & 1.01 & 3.0 & 10 \\
\hline
\end{tabular}
calibration curves ranged from 1.01 to 1.20 (Table 2). In general,

Table 2 The standard curve in solvent and matrix of carfentrazone-ethyl and carfentrazone enantiomers 
significant suppression or enhancement effects were observed as the slope ratios were $\geq 10 \%$. Finally, the matrix-matched standards were utilized for quantification to obtain more realistic results in this work. The LOD and LOQ of carfentrazone-ethyl and the carfentrazone enantiomers in the soils were $0.5-3.0 \mu \mathrm{g} \mathrm{kg}^{-1}$ and 1.7$10 \mu \mathrm{g} \mathrm{kg}^{-1}$, respectively. The typical LC-MS/MS chromatograms was showed in Fig. 1.

\subsection{Stereoselective degradation of carfentrazone-ethyl and carfentrazone enantiomers in soils}

The degradation data of the carfentrazone-ethyl enantiomers in Jiangxi soil were showed in Table 3. The degradation of the carfentrazone-ethyl enantiomers in the Jiangxi soil followed a first-order kinetics with $R^{2}$ ranged from 0.7141 to 0.7160 . The carfentrazone-ethyl was fast degraded with the half live of $2.7 \mathrm{~d}$. Simultaneously, the carfentrazone enantiomers was formed with the degradation of carfentrazone-ethyl and reached a maxima of $2.41 \mathrm{mg} \mathrm{kg}^{-1} 1.20 \mathrm{mg} \mathrm{kg}^{-1}$ at $8 \mathrm{~h}$ in the incubation of carfentrazone-ethyl (Fig. 4). Then, the carfentrazone enantiomers were slowly degraded. There was slight stereoselective degradation for carfentrazone-ethyl enantiomers with the EF values ranging from $0.51-0.57$ in Jiangxi soil (Fig. 3A) and the $R$ (-)-carfentrazone-ethyl was preferentially degraded.
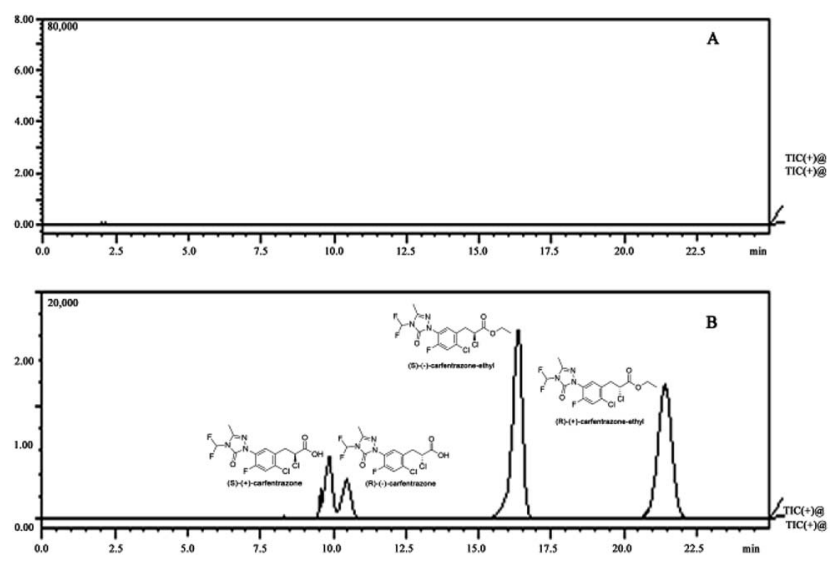

Fig. 1 Typical enantioseparation LC-MS/MS chromatograms: (A) blank soil sample, (B) soil spiked with carfentrazone-ethyl and carfentrazone at $0.2 \mathrm{mg} \mathrm{kg}^{-1}$.
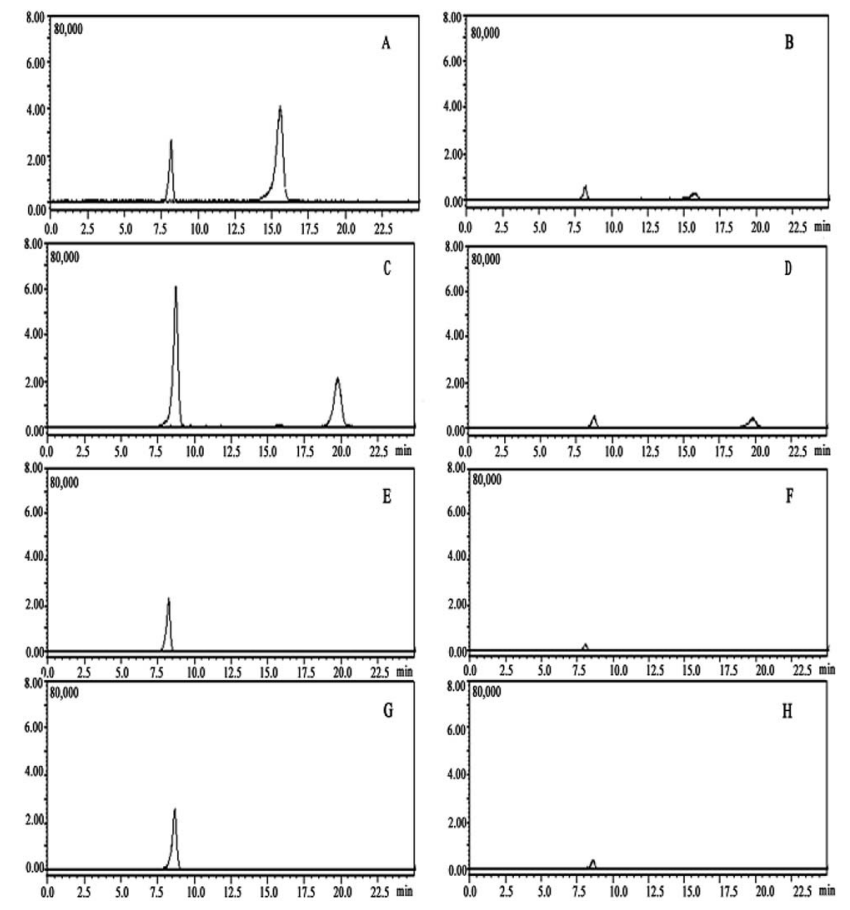

Fig. 2 Typical enantioselective degradation LC-MS/MS chromatograms in Jilin soil: (A) $S-(-)$-Carfentrazone-ethyl in soil at $2 \mathrm{~h}$. (B) $S$ $(-)$-Carfentrazone-ethyl in soil at $5 \mathrm{~d}$. (C) $R-(+)$-Carfentrazone-ethyl in soil at 2 h. (D) $R-(+)$-Carfentrazone-ethyl in soil at 5 d. (E) $S-(+)-C a r-$ fentrazone in soil at $2 \mathrm{~h}$. (F) $\mathrm{S}-(+)$-Carfentrazone in soil at $5 \mathrm{~d}$. (G) $R-$ $(-)$-Carfentrazone in soil at $2 \mathrm{~h}$. (H) $R-(-)$-Carfentrazone in soil at $5 \mathrm{~d}$.

The stereoselective degradation results of carfentrazoneethyl enantiomers in Jilin black soil was showed in Table 3. The degradation of the carfentrazone-ethyl enantiomers in Jilin black soil conformed to the first-order kinetics with the half life of $4.2 \mathrm{~d}$ and $4.1 \mathrm{~d}$, respectively. Over $90 \%$ of the carfentrazoneethyl enantiomers were degraded in $1 \mathrm{~d}$. The carfentrazone was also observed in the incubation of carfentrazone-ethyl. The concentration of carfentrazone increased early period and then began to decline after reached the maximum at $8 \mathrm{~h}$ (Fig. 4). There was remarkable stereoselective degradation for carfentrazone-ethyl enantiomers with the EF values ranging from 0.52 to 0.65 in Jilin soil (Fig. 3A).

Table 3 Half-lives $\left(T_{1 / 2}\right)$ and correlation coefficients $\left(R^{2}\right)$ of carfentrazone-ethyl and carfentrazone enantiomers in soils

\begin{tabular}{|c|c|c|c|c|}
\hline Soil type & Enantiomers & Half-life (days) & Curve equation & Correlation coefficient, $R^{2}$ \\
\hline \multirow[t]{2}{*}{ Jiangxi red soil } & $S$-(-)-Carfentrazone-ethyl & 2.7 & $y=1.2799 \mathrm{e}^{-0.258 x}$ & 0.7141 \\
\hline & $R$-(+)-Carfentrazone-ethyl & 2.7 & $y=1.0648 \mathrm{e}^{-0.257 x}$ & 0.7160 \\
\hline \multirow[t]{2}{*}{ Jilin black soil } & $S$-(-)-Carfentrazone-ethyl ${ }^{a}$ & 4.2 & $y=3.1901 \mathrm{e}^{-0.166 x}$ & 0.8251 \\
\hline & $R$-(+)-Carfentrazone-ethyl ${ }^{a}$ & 4.1 & $y=1.757 \mathrm{e}^{-0.171 x}$ & 0.7378 \\
\hline \multirow[t]{4}{*}{ Jilin black soil } & $S$-(-)-Carfentrazone-ethyl ${ }^{b}$ & 4.1 & $y=0.1534 \mathrm{e}^{-0.171 x}$ & 0.7792 \\
\hline & $R$-(+)-Carfentrazone-ethyl ${ }^{b}$ & 5.0 & $y=0.1308 \mathrm{e}^{-0.14 x}$ & 0.7491 \\
\hline & $S$-(+)-Carfentrazone ${ }^{b}$ & 4.7 & $y=0.3384 \mathrm{e}^{-0.146 x}$ & 0.9475 \\
\hline & $R-(-)$-Carfentrazone $e^{b}$ & 4.3 & $y=0.3326 \mathrm{e}^{-0.161 x}$ & 0.7774 \\
\hline \multirow[t]{2}{*}{ Anhui paddy soil } & $S$-(-)-Carfentrazone-ethyl & 4.2 & $y=1.7746 \mathrm{e}^{-0.164 x}$ & 0.627 \\
\hline & $R$-(+)-Carfentrazone-ethyl & 4.8 & $y=0.85332 \mathrm{e}^{-0.143 x}$ & 0.6175 \\
\hline
\end{tabular}

${ }^{a}$ The degradation of racemate carfentrazone-ethyl. ${ }^{b}$ The degradation of enantiopure carfentrazone-ethyl and carfentrazone. 

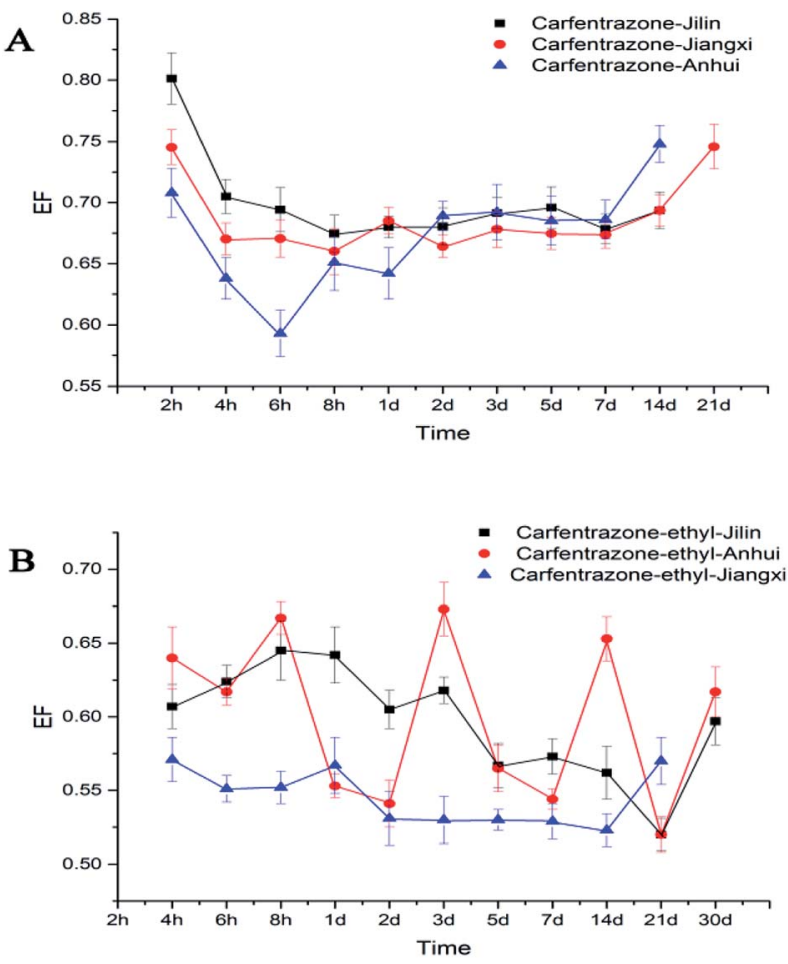

Fig. 3 The EF value of carfentrazone-ethyl and carfentrazone enantiomers in three kinds of different soils: (A) the EF value of carfentrazone enantiomers in Jiangxi red soil, Jilin black soil and Anhui paddy soil; (B) the EF value of carfentrazone-ethyl enantiomers in Jiangxi red soil, Jilin black soil and Anhui paddy soil.

The degradation tendency of enantiopure carfentrazone-ethyl and carfentrazone enantiomers in Jilin soil indicated that there was no bidirectional chiral inversion occurred. From the representative of Jilin soil, we can notice that the enantioselectivity of carfentrazone-ethyl and carfentrazone enantiomers was determined by the different degradation rate of enantiomers (Fig. 2).

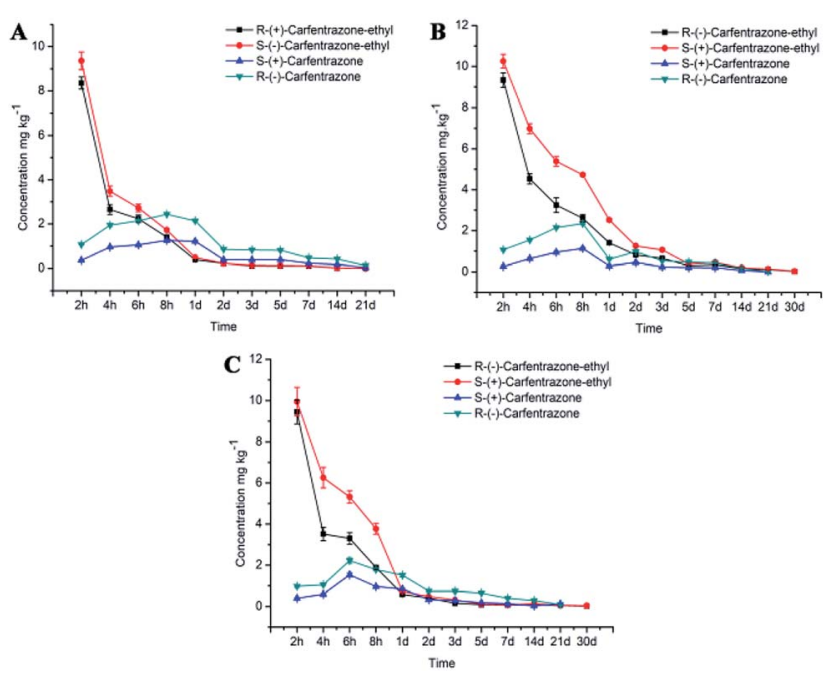

Fig. 4 Degradation of carfentrazone-ethyl and carfentrazone enantiomers in three kinds of soils: (A) the carfentrazone-ethyl and carfentrazone enantiomers in Jiangxi red soil; (B) the carfentrazone-ethyl and carfentrazone enantiomers in Jilin black soil; $(C)$ the carfentrazone-ethyl and carfentrazone enantiomers in Anhui paddy soil.
The stereoselective degradation results of carfentrazoneethyl enantiomers in the Anhui paddy soil were shown in Table 3. The degradation of the carfentrazone-ethyl enantiomers was described by a first-order kinetics equation with $R^{2} \geq$ 0.6175 . Same soil as the other two places, the concentration of carfentrazone increased at first and then decreased with the passage of time (Fig. 4). The half-lives of $S$-(+)-carfentrazoneethyl and $R$-(-)-carfentrazone-ethyl were $4.2 \mathrm{~d}$ and $4.8 \mathrm{~d}$, respectively. The EF of the carfentrazone-ethyl enantiomers was in the range of 0.51 to 0.67 , which showed certain stereoselective degradations (Fig. 3A).

In a summary, the order of degradation rates in three kinds of soil was Jiangxi > Jilin > Anhui, and the stereoselectivity in Jilin performed more remarkable. In addition, the formation content of carfentrazone enantiomers was not equal in the incubation of carfentrazone-ethyl and the content of $R$-(-)-carfentrazone was more than $S$-enantiomer.

\section{Conclusions and discussions}

In this study, a chiral analysis method of carfentrazone-ethyl and its chiral metabolite enantiomers in the soils was established using optimized QuEchERS method and LC-MS/MS.

The carfentrazone-ethyl enantiomers were fast degraded in three types of soils with the half-lives ranged from $2.7 \mathrm{~d}$ to $4.8 \mathrm{~d}$. Carfentrazone generated very quickly with the degradation of carfentrazone-ethyl. The concentration of carfentrazone stereoisomer increased steadily to a maximum and then decreased slowly. Therefore, the carfentrazone may play a major role to control weeds in agricultural management. The degradation of carfentrazone-ethyl and carfentrazone enantiomers in the three types of soils possesses significant stereoselectivity. And carfentrazone enantiomers performed stronger stereoselectivity than carfentrazone-ethyl enantiomers. The $R$ - $(+)$-carfentrazone-ethyl was preferentially degraded in the early period, causing the accumulation of $R$-(-)-carfentrazone. This interesting phenomenon led to the significant enantioselectivity of carfentrazone enantiomers. This result may be explained by the predominance of microbial populations or consortia preferentially degrading the $R$-enantiomer or on the activation/inhibition of enantiomerspecific enzymes. ${ }^{16}$ The mechanism of the stereoselective degradation behaviour of carfentrazone-ethyl and the carfentrazone enantiomers in the soils need the further research. The data obtained in this study could provide support for environmental risk evaluation of pesticides.

\section{Conflicts of interest}

No conflict of interest exists in the submission of this manuscript.

\section{Acknowledgements}

This work was supported by the National Key Research and Development Program of China (2016YFD0200207) and the Project of Science and Technology Innovation team from Anhui Academy of Agricultural Sciences (14C1105). 


\section{References}

1 M. Wang, Q. Zhang, L. Cong, W. Yin and M. Wang, Chemosphere, 2014, 95, 241-246.

2 V. Pérez-Fernández, M. García and M. L. Marina, J. Chromatogr. A, 2011, 1218, 6561-6582.

3 I. Buerge, A. Bächli, J. De Joffrey, M. Müller, S. Spycher and T. Poiger, Environ. Sci. Technol., 2012, 47, 6806-6811.

4 P. Xu, J. Diao, D. Liu and Z. Zhou, Chemosphere, 2011, 83, 1074-1079.

5 F. Dong, J. Li, B. Chankvetadze, Y. Cheng, J. Xu, X. Liu, Y. Li, X. Chen, C. Bertucci, D. Tedesco, R. Zanasi and Y. Zheng, Environ. Sci. Technol., 2013, 47, 3386-3394.

6 M. Asad, M. Lavoie, H. Song, Y. Jin, Z. Fu and H. Qian, Sci. Total Environ., 2017, 580, 1287-1299.

7 Q. Zhang, M. Tian, M. Wang, H. Shi and M. Wang, J. Agric. Food Chem., 2014, 62, 2809-2815.

8 D. Lewis, A. Garrison, K. Wommack, A. Whittemore, P. Steudler and J. Melillo, Nature, 1999, 401, 898-901.

9 M. Tian, Q. Zhang, X. Hua, B. Tang, B. Gao and M. Wang, J. Hazard. Mater., 2016, 320, 487-494.

10 Y. Tao, F. Dong, J. Xu, X. Liu, Y. Cheng, N. Liu, Z. Chen and Y. Zheng, J. Agric. Food Chem., 2014, 62, 11457-11464.

11 P. Qi, Y. Yuan, Z. Wang, X. Wang, H. Xu, H. Zhang, Q. Wang and X. Wang, J. Chromatogr. A, 2016, 1449, 62-70.
12 H. Zhang, X. Wang, S. Zhuang, N. Jin, X. Wang, M. Qian, H. Xu, P. Qi, Q. Wang and M. Wang, J. Agric. Food Chem., 2012, 60, 10188-10195.

13 F. Dong, X. Liu, Y. Zheng, Q. Cao and C. Li, Chirality, 2010, 22, 292-298.

14 B. Gao, Q. Zhang, M. Tian, Z. Zhang and M. Wang, Anal. Bioanal. Chem., 2016, 408, 6719-6727.

15 Z. Zhang, Q. Zhang, B. Gao, G. Gou, L. Li, H. Shi and M. Wang, J. Agric. Food Chem., 2017, 65, 8241-8247.

16 I. Buerge, T. Poiger, M. D. Muller and H. R. Buser, Environ. Sci. Technol., 2003, 37, 2668-2674.

17 E. Romero, M. B. Matallo, A. Pena, F. Sánchez-Rasero, P. Schmitt-Kopplin and G. Diosa, Environ. Pollut., 2001, 111, 209-215.

18 T. Poiger, M. D. Müller, H. R. Buser and I. J. Buerge, J. Agric. Food Chem., 2015, 63, 2583-2590.

19 D. Sun, J. Pang, J. Qiu, L. Li, C. Liu and B. Jiao, J. Agric. Food Chem., 2013, 61, 11273-11277.

20 X. Zhang, X. liu and C. Lu, Plant Protection, 2012, 38, 115119.

21 K. Kgim and D. Crosby, Environ. Toxicol. Chem., 2001, 20, 485-490.

22 J. Duan, X. Dong, Y. Shen, B. Gao, Z. Zhang, T. Gao and M. Wang, J. Sep. Sci., 2018, 41, 3697-3705.

23 X. Pan, F. Dong, Z. Chen, J. Xu, X. Liu, X. Wu and Y. Zheng, J. Chromatogr. A, 2017, 1525, 87-95. 